\title{
Next Generation Material for Denture Teeth and Denture Base Material: Limpet Teeth (LT) as an Alternative Reinforcement in Polymethylmethacrylate (PMMA)
}

\author{
Arun Y. Patil1,"*, Akash Naik¹, Bhavik Vakani², Rahul Kundu², N.R. Banapurmath ${ }^{1}$, M. Roseline ${ }^{3}$, \\ Lekha Krishnapillai ${ }^{3}$, Shridhar N. Mathad ${ }^{4, \dagger}$ \\ 1 School of Mechanical Engineering, Centre for Material Science, K.L.E Technological University Earlier Known as \\ B.V.B. College of Engineering and Technology, Hubli, India \\ 2 Department of Bio Sciences, Saurashtra University, Rajkot, India \\ ${ }^{3}$ Prosthodontics Department, S.D.M College of Dental Science and Hospital, Dharwad, Karnataka, India \\ ${ }^{4}$ Department of Engineering Physics, K.L.E. Institute of Technology, Hubli, India
}

(Received 12 March 2021; revised manuscript received 15 April 2021; published online 20 April 2021)

\begin{abstract}
Today, oral disorders are the most prominent and common issues in the world. Investigations reveal oral disorders comprising of gum disease, tooth decay, mouth sores, tooth erosion, tooth sensitivity, toothaches, and dental emergencies. Further, in-depth study identifies improper bonding between denture base and denture teeth ending up with costly repair along with mouth sores. This effect is observed from middle age (35 years) to old age ( $<80$ years) people in the world. Approximately one-third of the population is suffering because of untreated caries of natural teeth (31.2 \%). The optimal composition of PMMA as denture base and denture teeth in clinical trials with observation and experimental methodology is yet to be unleashed. An alternative material for denture base or denture teeth is still an unanswered question. Selection of appropriate reinforcement material encompassing the guidelines for liquid/powder ratio, avoids processes terrible for bond strength, the wax free model. The current work focuses on investigation of mechanical properties with/without the reinforcement of a new biomaterial known as limpet teeth (LT). LT is abundantly available in the seashore or intertidal regions. Application of LT in dentistry or as a denture base material is unperceived. A comparative analysis of coupons with/without the reinforcement (in the form of a short/continuous fiber) of LT in PMMA is carried out. The simulation work correlates with experimental work exploring the possibilities of a new material in the field of dentistry. The observed results for mechanical properties such as flexural strength (106\%), microhardness (116\%) and impact strength $(125 \%)$ are better in comparison to base PMMA material.
\end{abstract}

Keywords: Polymers, Biopolymers, Mechanical properties of solids.

\section{INTRODUCTION}

Fatigue life and failure of denture teeth and denture base materials have not yielded any fruitful results to dental community [1, 2]. PMMA as a denture base and denture teeth is characterized by early staining, noise during the mastication process, low impact strength, shelf life, unpredictability and inconsistency [3]. Till date, there have been no such attempts to achieve an optimal condition of PMMA for denture base, denture teeth, clinical trials and process methodology. Fiber-based reinforcement was tried with glass fiber [4-9], silanized glass fiber [10-12], aramid [13, 14], polyethylene [15, 16], polypropylene [17], OPEFB [18], vegetable fiber [19] in holding matrix PMMA to know the mechanical properties, such as flexural strength, microhardness and impact strength. Since ancient days, biomaterial has been used in human body for the betterment. To this, the latest entrant is limpet teeth (LT). Limpets are known for many reasons, they are the most primitive molluscan class of the total molluscan diversity known. Most limpets live on rock and feed on algae. These animals feed on algae with their ribbon-like tongue, which has rows of teeth like a structure called radula, as shown in Fig. 1. Limpets move in a wave-like motion with the help of muscles present in their foot. Some predators in the intertidal zone, such as shorebirds, fish, and sometimes humans prey on limpets. Most limpets disperse their eggs and sperm once a year, usually during the winter season. Larvae float in the sea for about a couple of weeks before settling on a hard substrate [20,21]. Researchers consider LT as a new biomaterial for dentistry [22] in a denture base. It is quite possible that in the coming days it will replace many other materials with various domains. Simulation using J-OCTA, ANSYS and many other tools makes life easier for researchers [23, 24].

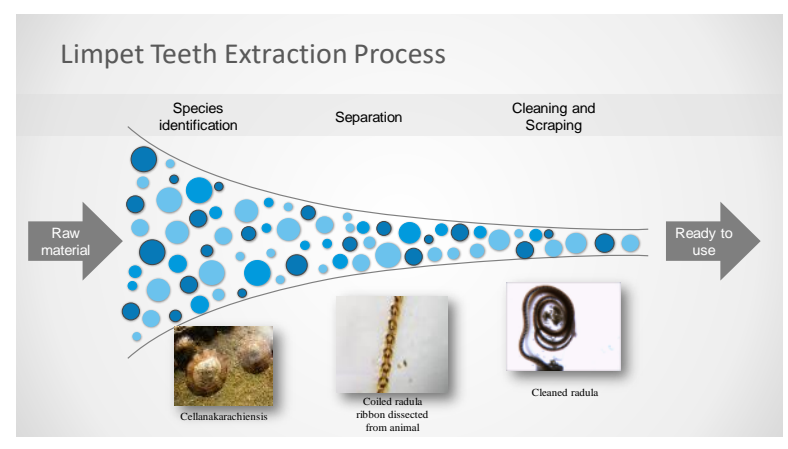

Fig. 1 - Limpet teeth extraction procedure

\footnotetext{
* patilarun7@gmail.com

$\dagger$ physicssiddu@gmail.com
} 
The molluscan radula is a unique characteristic and is found in all groups of molluscs, except bivalves [25]. Radula's mechanical properties are mostly affected by the size, form, material of the teeth, nutritive material properties as well as the reactions between teeth and nutrition which determine the need of each species for a special radula [26].

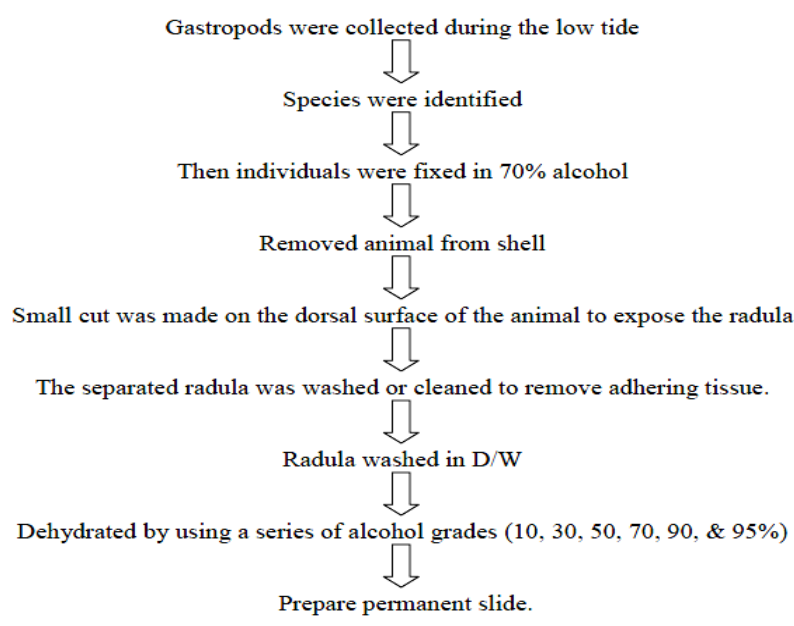

Fig. 2 - Methodology of the work

The standard formula of the radula is as follows: $\mathrm{M}+\mathrm{L}+\mathrm{R}+\mathrm{L}+\mathrm{M}$. Each row of the radula has one central or middle tooth $(\mathrm{R})$, a few lateral teeth $(\mathrm{L})$ on each side and then beyond that a few marginal teeth (M) as highlighted in Fig. 1. Different species may have different lateral teeth, and there are many marginal teeth that are too many to count (in our selected species, there are no marginal teeth).

In the case of our selected species, we observed a long radula, about three times the length of the animal. One minimal spear-shaped rachidian tooth is observed in the group. Here, the radula is of the Docoglossan type and the formula is $1+\mathrm{D}+1+1+1+\mathrm{D}+1$.

To separate the radula from the animal, an individual sample of the gastropod mollusc separated from the shell, a small cut was made on the dorsal surface of the head until the radula was exposed [27] as shown in Fig. 2. Then, the dissection was done till the end of the snout, and along with the tongue-like odontophore was detached from the muscle fibers attached to it [28]. The separated radula was washed or cleaned in dilute acidic medium with a soft brush to remove adhering tissue. The radula was then washed by fresh distilled water and dehydrated by using a series of alcohol grades (10, $30,50,70,90,95 \%)$ to prepare further experiments [29].

\section{MATERIAL AND METHODOLOGY}

Bioline reagents is a manufacturer of molecular biology products for the life sciences industry and research markets. It has applications in many areas such as medicine, biotechnology and marine biology, food and agricultural technology, forensic and environmental sciences. Bioline petroleum jelly is used as a cleaning reagent for molds used for specimens. The patterns are prepared in such a way that at least five samples are extracted per cycle. Surface preparation ensures the coupons are manufactured under standard molding conditions.
Material is available in powder and liquid forms, and the coupons are prepared using powder and liquid reagent material. It contains acrylic. The liquid and powder are mixed in the ratio of 1:2 to make the mixture. The mixture is stirred, and a paste is formed (pink in color). The mixture is kept open to the atmosphere for 5 min. The molten mass is now getting bonded like bubble gum. There are two specimens prepared for testing. One sample contains pieces of teeth and the other does not contain any teeth. The two specimens are subjected to various mechanical tests like micro UTM, hardness and compression tests. The clamp after bench pressing placed in a curing box. The box contains normal tap water at $25^{\circ} \mathrm{C}$. The temperature rise is gradual, and the maximum temperature rise is $72{ }^{\circ} \mathrm{C}$. The water is heated with the help of an electrical coil and cooled under tap water. The average cycle time is $90 \mathrm{~min}$. A high temperature is required for the mixture to solidify.

Fig. 3 represents the mold set under the clamp. The clamp is situated in the bench pressing. The clamp is placed under the bench pressing for 30 to $45 \mathrm{~min}$. The maximum pressing load is $50 \mathrm{kN}$. This process is done to remove an extra portion of the bonded mixture and to strengthen the bond. Later, clamp is placed in the curing box.

The specimen is ready for trimming and cleaning service. The operation is performed after the specimen is taken out of the mold. The machine has two wheels. One wheel contains cotton cloth, whereas the other is solid. Pumice powder is used along with a cotton wheel to clean the specimen. The other motor is to remove an extra portion of the coupon after removing it from the mold. The coupon after this operation is even. The powder will give a smooth surface finish. This operation is performed to get the exact dimension of the mold. Fig. 4 illustrates the machines used for machining operations. The speed (rpm) of motor is adjusted according to the type of mandrel. The process is partially automated and requires a skilled person to operate as the accuracy of dimensions is needed. Sandpaper is used to smooth the surface of the specimen.

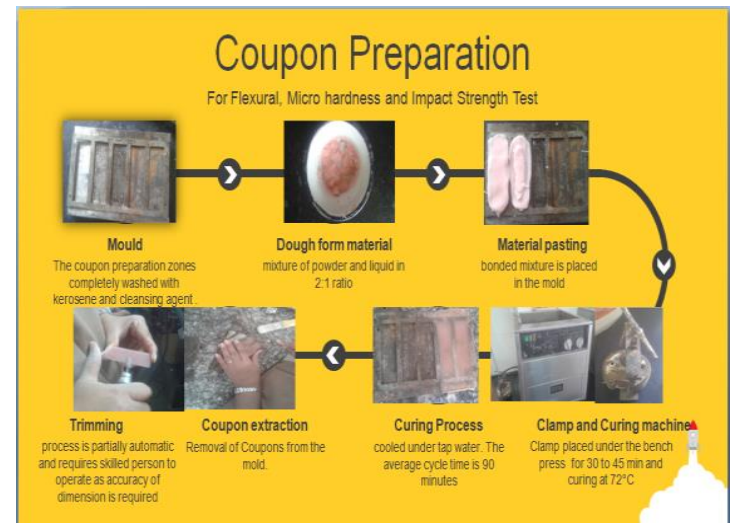

Fig. 3 - Process map for the coupon preparation

\section{RESULTS AND DISCUSSION}

The three denture base acrylic (with two of them reinforced with LT fiber) samples were subjected to 3 point flexural test with a uniform line load of $980 \mathrm{~N}$ acting at the center at room temperature of $25^{\circ} \mathrm{C}$. The 
standard followed for flexural strength analysis was D 790. The mean speed of the load indenter was $5 \mathrm{~mm} / \mathrm{min}$. The gauge length and span length were $50 \mathrm{~mm}$ and $40 \mathrm{~mm}$, respectively. There was no pretensioning load on the specimens. The upper parts of the samples were subjected to compression, while the lower parts were subjected to tension. Following the test, the three specimens were broken down into two pieces. The reinforced example showed an increase in flexural strength and peak deformation. The reinforced elongated fiber showed the highest flexural strength among the three samples with $103.479 \mathrm{MPa}$, the peak load and peak deformation during fracture were 216.972 $\mathrm{N}$ and $4.5 \mathrm{~mm}$. The second specimen, having a staggered limpet fiber, had a fracture path along one of the fibers, while in the other two samples the fracture path did not cut the fiber. The flexural strength, peak load, and peak deformation were 98.59 MPa, 205.408 N and $3.8 \mathrm{~mm}$, respectively. The third sample, which had no fibers, had the lowest flexural strength but the maximum peak load. The values were 97.173 MPa, $253.722 \mathrm{~N}$, and $3.5 \mathrm{~mm}$ of peak deformation, respectively. The observation depicts that flexural strength increases with reinforcement, while peak load decreases with support. The fracture did not divide the specimen into two equal parts. There were no cracks observed in any part of the material after fracture.
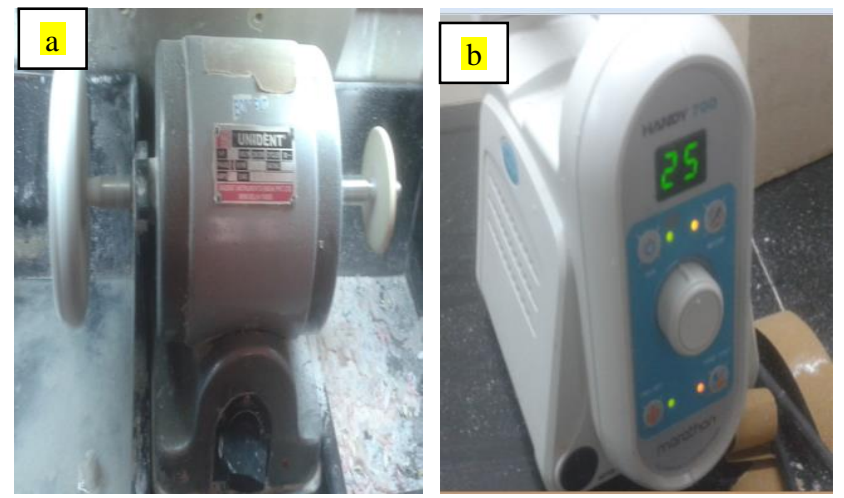

Fig. 4 - (a) Dental lathe machine; (b) handy trimmer

The theoretical value for 3-point flexural strength is calculated using formula $\left(3 F L / 2 b d^{2}\right)^{30}$, where $F$ is the peak load, $L$ is the span length, $b$ is the width and $d$ is the depth of the cross-section. By using the formula, flexural strength for elongated fiber is $103.479 \mathrm{MPa}$, 98.59 MPa for staggered fiber and 97.173 MPa for nonreinforced specimen. The theoretical values when compared to actual values were matching.

Fig. 5 illustrates the load versus stress plot for three cases: WF (without fiber), CF (continuous fiber), and SF (short fiber). The load in sample 1 is $253 \mathrm{~N}$, in sample 2 is $216 \mathrm{~N}$ and for sample 3 is $205 \mathrm{~N}$. Samples 2 and 3 show the low load due to high load-bearing capacity or stress rigidity by LT either in continuous or short fiber forms. The load versus strain plot is highlighted in Fig. 6 and explains changes in length with load increase.

Fig. 7 discusses load versus elongation in which the CF-based (sample 2) coupon is subjected to elongation of $9.2 \%$ compared to sample $3(7.6 \%)$ and sample 1 (7.2\%). Table 1 depicts the comparative study of all the three samples subjected to a flexural strength test.

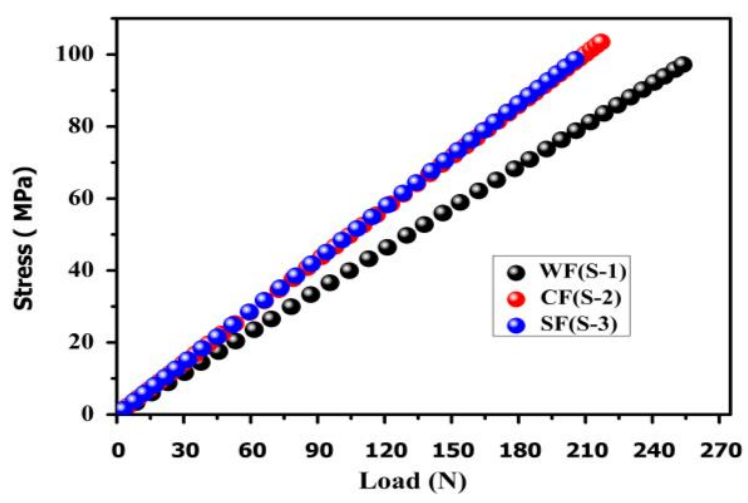

Fig. 5 - Load vs. stress for all the three samples

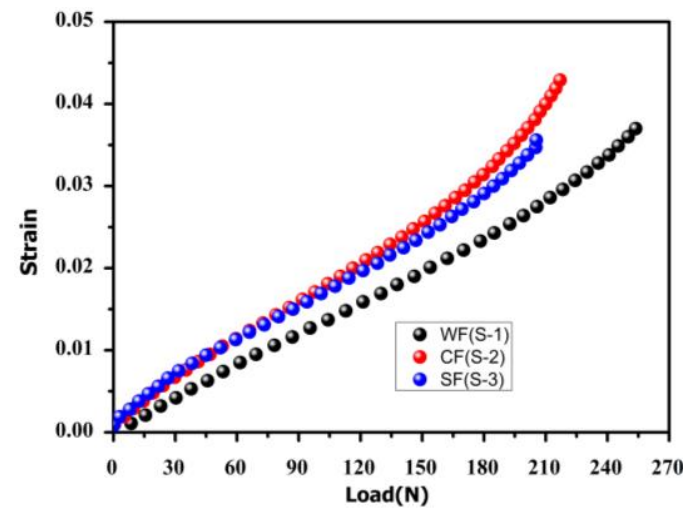

Fig. 6 - Load vs. strain of the samples

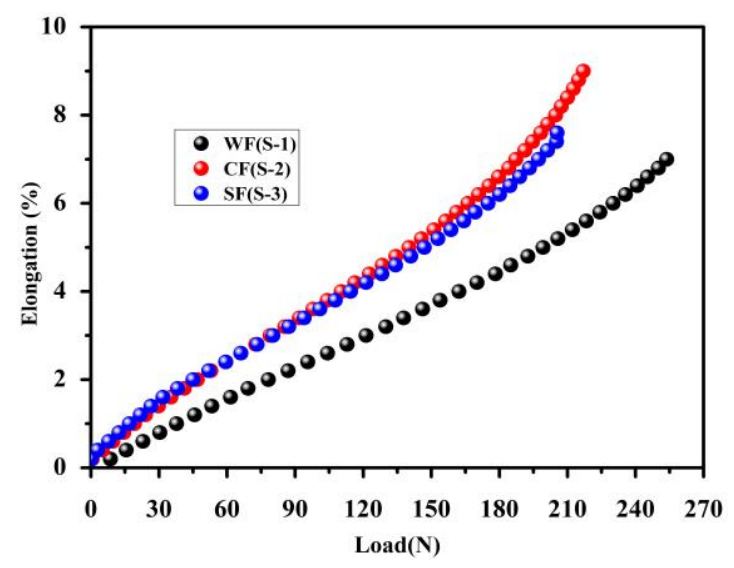

Fig. 7 - Load vs. elongation of the samples

Table 1 - Flexural strength results (error \pm 0.5 )

\begin{tabular}{|c|c|c|}
\hline No & Sample type & $\begin{array}{c}\text { Flexural strength } \\
\text { (in MPa) }\end{array}$ \\
\hline 1 & Sample 1(WF) & 97.17 \\
\hline 2 & Sample 2(CF) & 103.47 \\
\hline 3 & Sample 3(SF) & 98.59 \\
\hline
\end{tabular}

To study the flexural strength, the specimen was subjected to Vicker's microhardness test. The load applied was $50 \mathrm{~g}$ point load with the shape of the diamond indenter. The upper surface was fixed in each case, and the load was applied gradually from the bottom surface. The material used to hold the surface was generally made of PMMA. The next standard was ASTM E 384. The area of focus was the part where the reinforced fiber was located. The specimen used was of 
$25 \times 19.5 \times 2.54 \mathrm{~mm}^{3} \quad$ for $\quad$ elongated fiber, $28 \times 20 \times 2.5 \mathrm{~mm}^{3}$ for staggered fiber and $30 \times 19.7 \times 2.85 \mathrm{~mm}^{3}$ for non-reinforced fiber. The sample having elongated fiber showed maximum microhardness of $25.04 \mathrm{HV}$ as shown in Table 2.

Table 2 - Microhardness results (error \pm 0.15 )

\begin{tabular}{|c|c|c|}
\hline No & Sample type & $\begin{array}{c}\text { Microhardness (in } \\
\text { HV) for 50 g load }\end{array}$ \\
\hline 1 & Sample 1(WF) & 21.54 \\
\hline 2 & Sample 2(CF) & 25.04 \\
\hline 3 & Sample 3(SF) & 23.21 \\
\hline
\end{tabular}

The microhardness was uniformly spread until the fiber was present. Then, the microhardness started to decrease. The reason might be due to the maturity of posterior edge teeth in comparison to interior edge [31]. The organic structure of LT is complex as it comprises goethite orientations with various angles embedded in the chitin matrix. The goethite nanobased fibers, when viewed through field emission scanning electron microscope (FE-SEM), appear a few micrometer range length fibers [32]. The second sample, having staggered fibers, had a lower microhardness than the elongated one, but the value was higher than that of the non-reinforced sample with $23.21 \mathrm{HV}$. The distribution of microhardness was slightly uniform with values varying about the mean value of $23.21 \mathrm{HV}$ throughout the sample, while the sample without reinforced fiber had a microhardness of $21.54 \mathrm{HV}$ with uniform distribution. It was observed an increment in the microhardness value of $16.25 \%$ for the elongated fiber, while it was $7.75 \%$ for the staggered fiber. Microhardness increased with the reinforcement of fiber. The theoretical formula to calculate the microhardness used is $\mathrm{HV}=1.8544 \times F / d^{2}, F$ is in $\mathrm{kg}, d$ is the mean diagonal distance of pyramid indentation.

\subsection{Impact Strength}

Impact strength testing of three samples are highlighted in Table 3 . Coupon 3 has given an impact strength of $179.9 \mathrm{~J} / \mathrm{m}$ compared to sample 2 and coupon 1 . The reason that sample 3 reports higher strength compared to others is due to the short fibers spread across the matrix and able to hold the matrix compared to continuous fiber or without fiber-based coupons. The impact strength is a critical parameter for denture applications. From Table 4, glass fiber, silanized fiber and aramid showed higher flexural strength in comparison to LT, but when it comes to impact strength, they lag behind the LT.

Table 3 - Impact strength results (error \pm 1 )

\begin{tabular}{|c|l|c|c|}
\hline No & \multicolumn{1}{|c|}{ Sample type } & $\begin{array}{c}\text { Impact value } \\
(\mathrm{J})\end{array}$ & $\begin{array}{c}\text { IZOD Impact } \\
\text { strength (J/m) }\end{array}$ \\
\hline 1 & Sample 1(WF) & 0.40 & 144.40 \\
\hline 2 & Sample 2(CF) & 0.35 & 140.00 \\
\hline 3 & Sample 3(SF) & 0.45 & 179.90 \\
\hline
\end{tabular}

However, availability of the material and cost of pristine sample is another concern for all synthetic fibers as LT is a biomaterial and is available in abun- dance in intertidal sea regions. The work still needs investigation of biocompatibility, chemical reaction with saliva and in-vivo and in-vitro conditions trials.

\subsection{Differential Scanning Calorimeter (DSC)}

DSC is a thermo-analytical method. It is used to study the behavior of material as a function of temperature or time. Melting point, crystallization behavior and chemical reaction are just some of the many properties or processes that can be measured by DSC. It measures the energy when subjected to heat, cool or held in isothermal conditions. The respective samples may undergo one or more phase changes during heating or cooling. These changes are called "thermal transitions" of a polymer. Examples of the thermal transitions are glass transitions, crystallization, and melting of a polymer. Fig. 8 illustrates three samples data extracted and analyzed for the common form and fit.
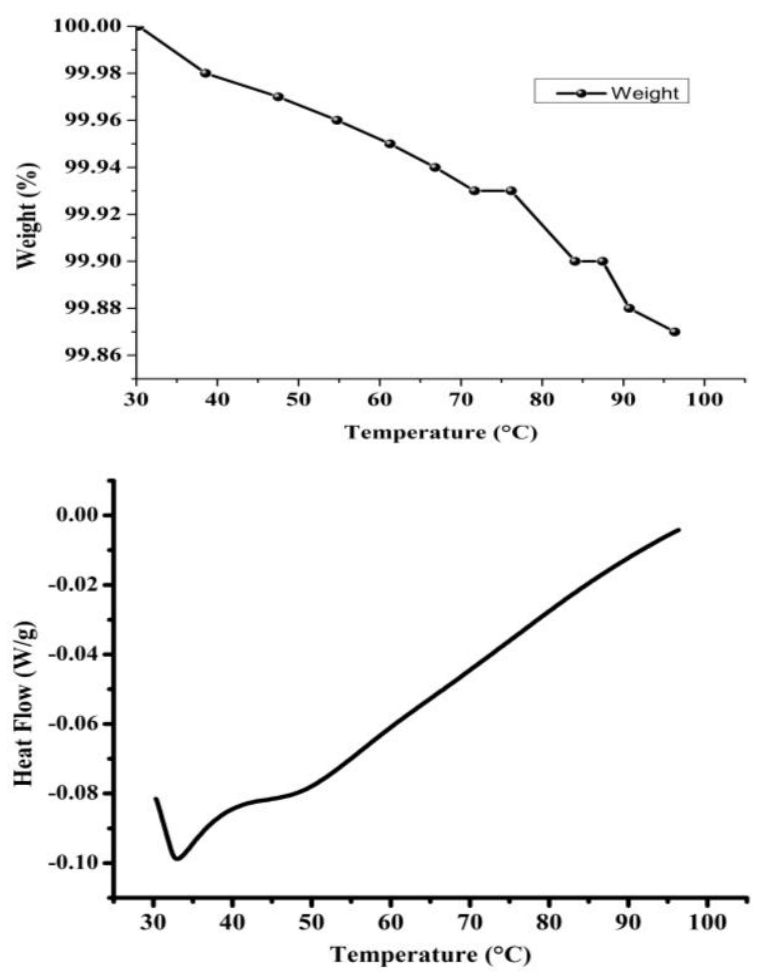

Fig. 8 - Differential scanning calorimeter measurements

Table 4 - Mechanical properties of various materials

\begin{tabular}{|l|c|c|c|}
\hline \multicolumn{4}{|c|}{ Polymer matrix PMMA } \\
\hline Reinforcement fiber & $\begin{array}{c}\text { Flexural } \\
\text { strength } \\
(\mathrm{MPa})\end{array}$ & $\begin{array}{c}\text { Micro- } \\
\text { hardness } \\
(\mathrm{BHN})\end{array}$ & $\begin{array}{c}\text { Impact } \\
\text { strength } \\
(\mathrm{J} / \mathrm{m})\end{array}$ \\
\hline Glass fiber [4-9] & $55.8-217.6$ & 32 & NA \\
\hline $\begin{array}{l}\text { Silanized glass } \\
\text { fiber [10-12] }\end{array}$ & 127.8 & NA & 77.9 \\
\hline Aramid [13-14] & $75.8-207$ & NA & NA \\
\hline Polyethylene [15-16] & NA & NA & 1220 \\
\hline Polypropylene [17] & NA & NA & 1100 \\
\hline $\begin{array}{l}\text { Oil palm empty } \\
\text { fruit bunch [18] }\end{array}$ & 110 & NA & NA \\
\hline Vegetable fiber [19] & 6.89 & NA & NA \\
\hline Limpet teeth & 103.47 & 25 & 179 \\
\hline
\end{tabular}




\section{CONCLUSIONS}

The exhaustive literature survey and the critical experimental work resulted in the following findings.

Limpet teeth of the Cellanakarachiensis species were extracted from the sea intertidal zones, and surface cleaning was carried out to avoid any foreign body intervention when used in the manufacture of the coupons. The coupons were tested for three different cases such as without fiber, with continuous fiber and with short fiber to cater to all possible options.

Mechanical properties such as flexural strength (1.06 times), microhardness(1.16 times) and impact strength (1.25 times) were better than PMMA as an original denture base material.

Limpet teeth are the most economically viable biomaterial, and, compared to other fiber materials, it has

\section{REFERENCES}

1. J.L. Cunningham, J. Dentistry 21 No 5, 274 (1993).

2. U. Darbar, R. Huggett, A. Harrison, Br. Dent. J. 176, 342 (1994).

3. Gabriel R. Zuckerman, J. Prosthetic Dentistry 89 No 6, 603 (2003).

4. Y.U. Sang-Hui, L.E. Yoon, O.H. Seunghan, C.H. Hye-Won, O.D. Yutaka, B.A.E. Ji-Myung, Dent. Mater. J. 31 No 6, 1039 (2012).

5. A.P. Farina, D. Cecchin, R.G. Soares, Gerodontology 29 No 2 , e-155 (2012).

6. I.M. Hamouda, M.M. Beyari, Oral Health Dent Manag. 13 No 1, 107 (2014).

7. M. Nagakura, Y. Tanimoto, N. Nishiyama, J. Biomed. Mater. Res. 105 No 8, 2254 (2017).

8. M. Dalkiz, D. Arslan, A.R. Tuncdemir, M.S. Bilgin, H. Aykul, Eur. J. Dent. 6 No 1, 70 (2012).

9. Yasuhiro Tanimoto, Manamu Nagakura, Norihiro Nishiyama, J. Prosthodont. Res. Jul. 62 No 3, 359 (2018)

10. S.H. Yu, D.H. Ahn, J.S. Park, Dental. Mater. J. 32 No 2, 332 (2013).

11. R.B Fonseca, I.N. Favarão, V.B. Kasuya, M. Abrão, N.F.M. Da Luz, L.Z. Naves, J. Mat. Sci. Chem. Eng. 2 No 2, 11 (2014).

12. T.K. Mowade, S.P. Dange, M.B. Thakre, V.D. Kamble, J. Adv. Prosthodont. 4 No 1, 30 (2012).

13. R.K. Jassim, A.A. Radhi, J. Bagh. Coll. Dent. 23 No 3, 6 (2011).

14. S.Y. Chen, W.M. Liang, P.S. Yen, J. Biomed. Mater. Res. 58 No 2, 203 (2001).

15. D.C. Jagger, A. Harrison, K.D. Jandt, J. Oral. Rehab. 26 No 3, 185 (1999). higher impact strength and is almost matching with glass fiber with the same percentage of inclusion in PMMA. Microhardness is compatible with all generic dental material building and utilization.

\section{ACKNOWLEDGEMENTS}

All are thankful to Prof. B.B. Kotturshettar, Head, School of Mechanical Engineering, K.L.E Technological University, Hubbali for his hand holding during work. We also thank our academic dean Prof. P.G. Tewari and Registrar Prof. B.L. Desai for their continuous support in the successful completion of the research work. We are also thankful to the Vice-Chancellor Prof. Ashok S. Shettar for providing motivation and morale support in completing the challenging task.

16. I.J. Ismaeel, H.A. Alalwan, M.J. Mustafa, J. Bagh. Coll. Dent. 27, 40 (2015)

17. J. John, M.S Ann, K. Palaniswamy, A. Ramanathan, A.A. Razak, J. Prosthodant 24 No 3, 233 (2015).

18. G. Uzun, N. Hersek, T. Tinçer, J. Prosthet. Dent. 81 No 5 , 616 (1999)

19. J. Xu, Y. Li, T. Yu, L. Cong, Dent. Mater. 29 No 12, 1273 (2013).

20. P. Arora, S.P. Singh, V. Arora, Int. J Biotech Trends Technol. 9, 1 (2015).

21. R.D. Purchon, The Biology of the Mollusca 2nd Edition (Pergamon Press: New York: 1977).

22. A.Y. Patil, N.R. Banapurmath, B.B. Kotturshettar, K. Lekha, M. Roseline, Fiber-Reinforced Nanocomposites: Fundamentals and App. 477 (2020).

23. A.Y. Patil, N.R. Banapurmath, S.Y. Jayachandra, B.B. Kotturshettar, Ashok S. Shettar, G.D. Basavaraj, R. Keshavamurthy, T.M. Yunus Khan, S.N. Mathad, Arab. J. Sci. Eng. 44, 7895 (2019).

24. A.Y. Patil, N.U. Hrishikesh, G.D. Basavaraj, K.G. Kodancha, G.R. Chalageri, Mater. Today Proc. 5 No 2, 7532 (2018).

25. D.R. Khanna, P.R. Yadav, Biology of Mollusca (Discovery Publishing House: New Delhi: 2004)

26. T. Ukmar-Godec, G. Kapun, P. Zaslansky, D. Faivre, J. Structural Biol. 192 No 3, 392 (2015).

27. S. Joseph, B. Vakani, R. Kundu, Mitochondrial DNA Part A 29 No 2, 181 (2018).

28. R. Ramesh, S. Ravichandran, Trend. Appl. Sci. Res. 3 No 2, 189 (2008). 


\title{
Матеріал нового покоління для зубних протезів та базовий матеріал протезів: зуби молюсків (LT) як альтернативне армування в поліметилметакрилаті (PMMA)
}

\author{
Arun Y. Patil ${ }^{1}$, Akash Naik ${ }^{1}$, Bhavik Vakani², Rahul Kunduㄹ, N.R. Banapurmath¹, Roseline M³, \\ Lekha Krishnapillai ${ }^{3}$, Shridhar N. Mathad ${ }^{4}$ \\ ${ }^{1}$ School of Mechanical Engineering, Centre for Material Science, K.L.E Technological University \\ earlier known as B.V.B. College of Engineering and Technology, Hubli, India \\ 2 Dept. of Bio Sciences, Saurashtra University, Rajkot, India \\ ${ }^{3}$ Prosthodontics Department, S.D.M college of Dental Science and Hospital, Dharwad, Karnataka, India \\ ${ }^{4}$ Department of Engineering Physics, K.L.E. Institute of Technology, Hubli, India
}

\begin{abstract}
На сьогодні порушення в ротовій порожнині е найбільш відомими та найпоширенішими проблемами у світі. Дослідження виявляють такі порушення, що включають захворювання ясен, каріес, виразки ротової порожнини, ерозію зубів, чутливість зубів, зубний біль та надзвичайні ситуації із зубами. Крім того, поглиблене вивчення виявляе неправильне зчеплення між основою протеза та протезними зубами, що призводить до дорогого ремонту разом із виразками ротової порожнини. Цей ефект спостерігається у людей від середнього (35 років) до похилого віку (< 80 років) по всьому світу. Приблизно третина населення страждає через відсутність лікування карієсу природних зубів (31,2 \%). Оптимальний склад РММА як основи протезування та протезних зубів у клінічних випробуваннях з методами спостереження та експериментальними методиками ще не розкритий. Альтернативний матеріал для зубних протезів досі залишаеться питанням без відповіді. Вибір відповідного армуючого матеріалу, що охоплюе керівні принципи щодо співвідношення рідина/порошок, дозволяе уникнути процесів, які впливають на міцність зчеплення, так звана модель без воску. Поточна робота зосереджена на дослідженні механічних властивостей з/без армування нового біоматеріалу, відомого як зуби молюсків (LT). LT достатньо доступний в прибережних або в приливних районах. Застосування LT в стоматології як основи для протезування залишається незамінним. Проведено порівняльний аналіз зразків з/без армування (у вигляді короткого/безперервного волокна) LT у PMMA. Результати моделювання корелюють з експериментальною роботою, що вивчае можливості нового матеріалу в галузі стоматології. Спостережувані результати щодо механічних властивостей, таких як міцність на вигин (106 \%), мікротвердість (116 \%) та ударна в'язкість (125 \%), кращі порівняно з базовим матеріалом РММА
\end{abstract}

Ключові слова: Полімери, Біополімери, Механічні властивості твердих речовин. 